\title{
報交
}

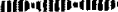

一般報交

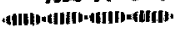

(昭和 55 年 3 月 18 日受理)

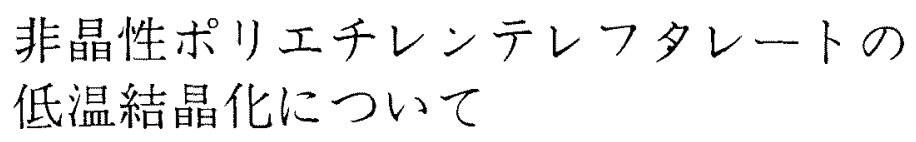

岡山大学工学部山下祐彦 ・物延一男

\section{ON THE COLD CRYSTALLIZATION OF POLY(ETHYLENE TEREPHTHALATE) FROM ITS GLASSY STATE}

\section{By Yuhiko Yamashita and Kazuo Monobe}

(School of Engineering, Okayama University, Thushima, Okayama)

In this paper we studied the molecular mechanism of the cold crystallization upon heating quenched Poly(ethylene terephthalate) (PET). From morphological observations we found spherulites in the samples annealed at lower temperature although it was deduced in early papers that cold crystallization occurs in the form of fringed micellar structure. The cold crystallization kinetics of PET was also examined by the dilatometric method. The dependence of the Avrami exponent on the thermal history indicated that the interpretation of crystallization process in terms of the Avrami treatment is inadequate. A structural similarity was found for samples crystallized by the solvent induced crystallization and by the cold crystallization. The DSC exothermic peak owing to the cold crystallization disappeared in cold drawn PET in which the changes of local chain conformation in glassy state occurred by stress. From these facts we discussed the molecular mechanism of cold crystallization in quenched PET.

(Received March 18, 1980)

\section{1. 緒言}

ポリエチレンテレフタレート(PET)は，結晶性高分 子であるが，その融液をガラス軽移温度以下に急椧する と，透明で準安定な非晶性固体になる。この凍結された 非晶性固体を熱処理するととによって起とる結晶化や結 晶化物の構造化ついては古く加ら多くの研究がある的。 それらの研究で，ての熱処理仯よる結晶化の特徵として 次の点が指摘されている。すなわち，ガラス転移温度以 上の $90^{\circ} \mathrm{C}$ 位から $180^{\circ} \mathrm{C}$ 位までさそれ以上融点儿近い温度 までの熱处理とで，密度やX線図から評価されるいわゆ る結晶化度の增加が二段階的に起とるという点である。， さらに, Kilian らのX線的研究にょるど)，高温での熱 処理物は，三次元的にオーダーのある結晶であるのに対
し，低温での熱処理物は，( $h k 0)$ 反射のみを示すような の軸方向に余り規則性のない不完全な結晶であるとされ ている。そして，低温熱処理物の構造の不完全性虫，て の温度範团の熱处理では分子の運動性が小さいだあであ るとされたが，それ以上結晶化の機構について言及され なかった。

この低温結晶化は差動熱量計などによる熱測定を，例 えば $10^{\circ} \mathrm{C} / \mathrm{min} の$ 昇温速度で行なうと， 135 C付近にピ 一クをもつ発熱として，とらえることが出来る19)、10 年程前に，三石らはこの発熱挙動に詳細な検討を加え， $\mathrm{X}$ 線測定に上る結晶化物の不完全性や電子顕微鏡観察で 明確な構造が認められないととを傍証として，ての低温 結晶化では総状ミャル的結晶化が起てっていると主張し た ${ }^{14)}$ 。 一方, 河合らも熱処理物の多重瀜解挙動の解析を 
中心にこの低温結晶化では分子間結晶化による束状晶の 生成が起とると主張した ${ }^{15)}$ 。当時，われわれは，融液か ら急冷したPETの非晶構造に興味を持ち，その解明を 目差したが，直接的研究手段のないのが実状であった。 そこで上記低温結晶化過程での分子集合状態の変化か 「凍結された非晶」の実態を解明する一つの鍵となると 考え研究を進めてきた。われわれの最終目標は，非晶構 造の解明にあったが ${ }^{16)}$ ，ててではその過程で明らかにな った低温結晶化の特徵について報告する。

\section{2. 実験}

\section{1 試 料}

非晶性PET試料としては，溶融押し出しでつくった 無配向非晶フィルムを用いた。〔ク〕 $=0.67$ で平均分子量 になおして 20,000 程度の試料であった。フィルムの厚さ は $180 \mu \mathrm{m}$ で，一部球晶の光学顕销鏡観察や赤外吸収 ペクトル測定のため，との非晶フィルムを再びホットプ レスで $20 \mu \mathrm{m}$ 程度の非晶薄膜に成型しなおして用いた。 成型条件は，充分乾燥したフィルムをアルミ管の間には さみ $285^{\circ} \mathrm{C} て ゙ 2$ 分間溶融し, ドライアイスメタノール中 に急冷した。荷性ンーダ溶液でアルミ箢を溶かし, 均一 な非晶フィルムを得た。なお，てのような再成型した試 料は, $[\eta]=0.55 \sim 0.61$ で分子量の低下がいくらか起と っていた。

\section{2 電子顕微鏡観察}

結晶化試料の内部組織を観察するため, 70\%エチルア ミン水溶液を結晶化フィルムの上に滴下し，1２時間 後に水洗し、はく離物がなくなるまでアセチルセルロー スでブランクレプリカをくり返し、レプリカ法で観察し た。電子顕微鏡は日立製HU-11 B 型を用いた。

2.3 ディラトメトリー

非晶性PETの低温結晶化過程を追跡するため,ディ ラトメーターに一定量の非晶試料をつめ, 水銀で封入し て体皘変化を調べた。相対的な体積変化加ら, 結晶化等 温線を得た。

\section{4 赤外吸収スペクトルの測定}

赤外吸収スペクトルの測定は日本分光製の IRA-2 型 赤外分光器を用いた。

\section{5 熱挙動の測定}

熱的挙動は, パーキンエルマー社製 DSC- 1 型差動熱 量計を用いて調べた。

\section{3. 結果および考察}

\section{1 低温結晶化物の微細構造}

溶融急泠した非晶性PETを低温結晶化領域の温度で 熱処理すると，偏光顕微鏡下に数ミクロンの組織を見い
出すととが出来る。この構造実態を明確にするため, 電 子顕微鏡による表面レプリカ像を観察したが, 三石らが 報告したように出）はっきりした形態を同定できなかっ た。そこで，エチルアミンを用いて試料表面をエッチン グし，内部組織を観察できるように工夫した。るの結果， 図1亿示すような数ミクロンの球晶組織を見い出すとと ができた。この球晶組織は, 高温で熱処理したときの球 晶にくらべると, ラメラ組織の明確さと欠りる。しか心, 球晶の境界は，はっきりしており，ラメラ状のフィブリ ルが一点を中心に放射状に成長しているのが分かる。 らに，偏光顕微鏡でも $20 \mu \mathrm{m}$ 程度の薄膜を用いれば，因 2 亿示すようなマルタ十字型の消光部をもつ正の球晶を 観察できることが分かった。

緒言で述べたように，三石ら ${ }^{14)}$ や河合ら ${ }^{16)}$ は，熱挙動 の解析から低温熱処理物の構造が分子間結晶化による総 状ミセル結晶あるいは束状結晶であると推定した。ての 推定は, 上述の球晶組織の観察加完全に否定される。

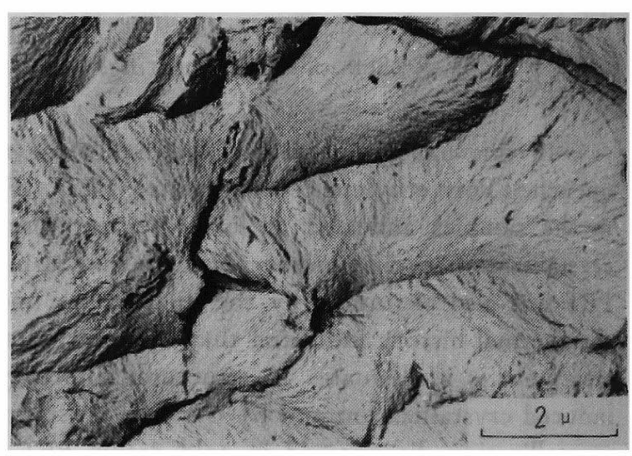

Fig. 1 Electron micrograph of ethyl amine-etched surface of PET. Polymer crystallized at $100^{\circ} \mathrm{C}$ from the glassy state. Spherulitic structure appears clearly.

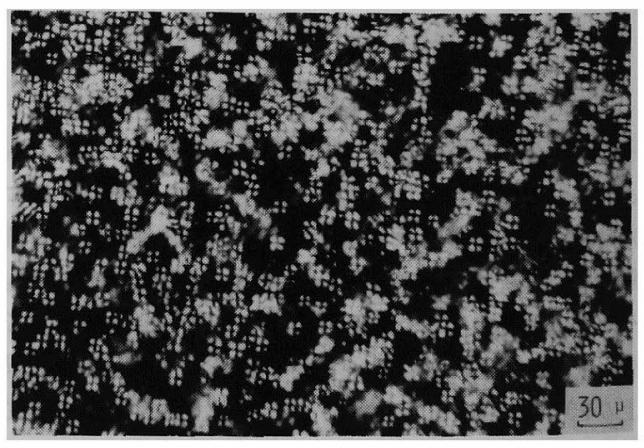

Fig. 2 Optical micrograph of thin film of PET. Polymer crystallized at $100^{\circ} \mathrm{C}$ from the glassy state. In thick film we can not observe the well-defined spherulites. 
また，との低温熱処理物は，Koenigによって ${ }^{17)}$ regular chain foldingに基つくとされている $988 \mathrm{~cm}^{-1}$ の赤外吸 収バンドを示す。との事実す，との熱処理物が折りたた み鎖結晶からなるととを示すすのであり，ての点からも 三石や河合らの推定は否定されよう。これまで，低温熱 処理物の組織構造を直接同定することの团難性が種々の 議論をよんでいたと考えられる。

\section{2 低温結晶化の動力学}

3.1 で示したように低温熱兔理物の構造は，高分子結 晶組織上して一般的な球晶組織であるてとが明らがな った。それで住，ての低温熱処理で非晶性PETの分子 凝集状態から球晶組織への変換は，どのような機構で起 てっているのであろうか。まず低温結晶化の速度的特 徽を調べた。溶融急椧でつくったPETの無配向非晶性 フィルムを用いて， $85^{\circ} \mathrm{C} \sim 120^{\circ} \mathrm{C}$ の温度範用でブィラト メーターによって結晶化を追跡した結果が図 3 である。 結果加ら明らかなよう亿熱処理時間の対数と体皘結晶化 量の間仙は逆 S字型の関係があり，各温度で重权合わせ 可能である。また，到達結晶化量は，熱处理温度とよも そやや增大しているが，余り大きな变化はない。变換速 度は正の温度依存性を示しており この变換過程が分子 鎖の熱運動に律速されているとよは明らかである。

てれまでにあ多くの研究者 ${ }^{1 \sim 3,7 \sim 10,14,13,18)}$ 亿よって， この低温結晶化の速度が測定さ㧈，Avrami ${ }^{20)}$ の相変換 の動力学理論で解析されている。しかし，それらの解析 結果調べてると，Avrami 指数 $n$ の值は，1４.5ま で種々の值が報告されている。そして、例えば $n=1^{8,14)}$ とか $n=2^{8,7,9,10)}$ の結果を得大研究者は，Avrami理諭で 解釈し，核生成が predetermined あるいは sporadicで 結晶の成長様式が䋐維状であると論じた。しかし，てれ

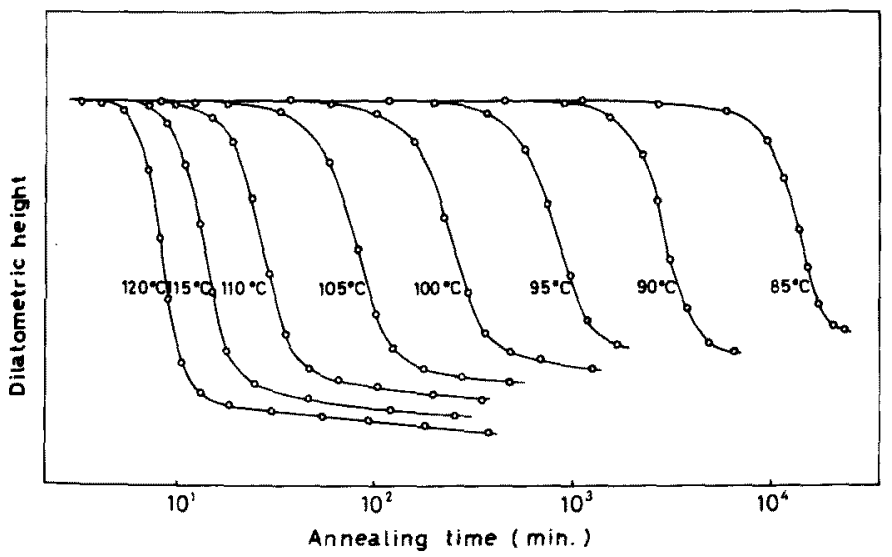

Fig. 3 Dilatometric isotherms of amorphous film of PET during cold crystallization.

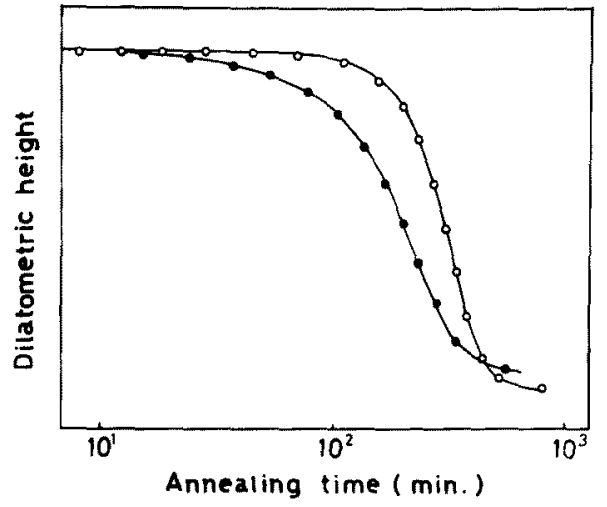

Fig. 4 The change of dilatometric isotherms on the thermal history. O Original amorphous film. Film annealed at $100^{\circ} \mathrm{C}$ for 130 min. and quenched into dry ice methanol mixture. Crystallization temperature $100^{\circ} \mathrm{C}$.

は低温熱起理物の構造が球晶であるという3.10結果之 矛盾する。一方， $n=4^{18)}$ とか $n=4.5^{19)}$ の結果を得た研 究者もAvrami 理論での解䣋を意図したが、明锥な結論 を下すまでに到っていない。われわれの結果から求めた

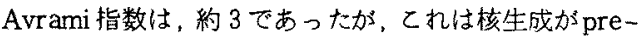
determined で結晶の成長様式が三次元として一応説明 できる。しかし，次の実験結果を考えると，上述の上う な結論を下すことは早計であるかもしれない。すなわち， 图 4 に示した結果は，100 Cで非晶性フィルムを熱処理 し，結晶化開始前に急冷後，再び昇温し結晶化させた例 である。原試料とはまったく巽なった等温線を示してお り，Avrami 指数も3加ら2まで下がる。との事実は， 非晶性PETの熱履歷によって Avrami 指数が変化する ととを示したものであり，非晶性固 体を熱処理して起こる低温結晶化に 対して単純に Avrami 理論を商用し， その分子機構を論ずることの危険性 を示している。Avramiの相変换理 論では，結晶の線成長速度が一定上 仮定され，核生成速度の時間俵存性 す多くの可能性のうち数例か論じら れているのみである ${ }^{26)}$ 。てれまでの 高分子融液加らの結晶化化対する Avrami 理論の適用の成功を背景に， 非昆性 PET の低温結晶化の動力学 が多くの研究者によって制限の多い Avrami 理論で解积しようと試みら れてきたが，むしろ非晶性PETの 構造をも踏まえた真の変換機構を検 
討するのが先決のようである。そのためには，もっと別 の手段でての低温結晶化の実態を検討してみる必要があ る。

\section{3 低温結晶化の実態}

低温結晶化での分子凝集状態の変化はどのようなあの であるかという問に，とれまでの他の研究者の実験結果 の中に二，三の解答が見い出されるように思う。すなわ ち，低温熱処理物の長周期が高温熱処理物之異なり，熱 妈理温度に依存せず一定であるという事実がある゙,22)。 もし低温結晶化過程が絡みあったランダムコイル鎖加ら 折りたたみ鎖に変換するような分子銷の大きな形態変化 をともなった過程なら，長周期に当然温度依存性があっ てよかろう。これに反し，長周期が一定であるという事 実はもとの非晶性 PET の構造中に長周期が由来するよ うな構造があり，それが低温熱処理で顕在化したとも考 えられる。

また，非晶性PETは，アセトンのような有機溶媒に 浸漬するととによって低温結晶化と同程度の結晶性を示 す ${ }^{23)}$ 。乙の場合, 膨潤するととなく室温で急速汇結晶化 が起とる。Sheldon ${ }^{24)}$ は，その速度過程が溶媒分子の試 料中への拡散によって律速された過程であると報告して いる。また，Zachmann ${ }^{25)}$ は，詳しい速度過程の検討か ら溶媒分子が非晶 PET 分子中に到達するやいなや結晶 化が起こっていると主張している。ての事実加ら考える と，との結晶化過程ではPET分子の大きな形態变化で 結晶化が起てっていると考えるととはできない。という のは溶媒分子によるPET銷の易動性が高められたとし ても，大きな形態変化を考える以上，自己拡散に基づく 時間依存性があるのが当然であろう。それ故，ての場合 の結晶化は PET中の極性基上溶媒分子の相互作用を通 して，PET鎖の局所的な形態変化で起こっていると考 えられる。

この考察を踏まえて，まず低温熱処理物之溶媒で誘起 された結晶の特徵を調べた。図 5 および図 6 にその結果 を示した。両結晶化物ともX線回折パターンは幅広い回 折ピークを示しており，不完全な結晶が生成しているて とが分かる。また赤外吸収スペクトルの上でも，いわゆ るトラスバンドの吸光度の增大とゴーシュバンドの吸光 度の減少がみられる。さらに $988 \mathrm{~cm}^{-1}$ の fold バンドの 吸光度屯両者で同じ程度の值を示す。溶媒誘起結晶化試 料では，非晶性 PET差動熱量計で加熱していった場 合にみられる低温結晶化発熱ピークが消失している。ま た，密度む1.370程度の值を示して，低温結晶化物の示 す値と同程度である。これら多くの構造的特徽の類似性 は，熱処理に上る低温結晶化物之溶媒で誘起された結晶 化物が，非晶状態から基本的に同じ分子機構で生成した

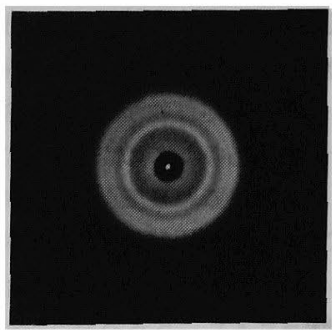

(a)

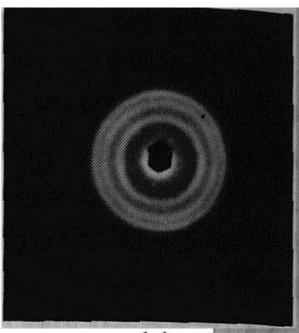

(b)

Fig. 5 X-ray photographs of PET. (a) Amorphous film immersed in acetone at $25^{\circ} \mathrm{C}$. (Solvent induced crystallization) (b) Amorphous film annealed at $95^{\circ} \mathrm{C}$. (Cold crystallization)

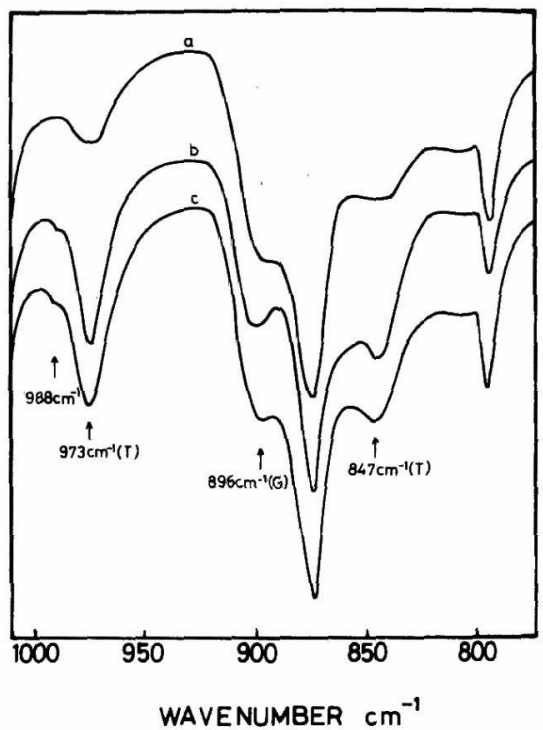

Fig. 6 Infrared absorption spectra of PET.

(a) Original amorphous film. (b) immersed in acetone at $25^{\circ} \mathrm{C}$. (c) annealed at $95^{\circ} \mathrm{C}$.

あのであるととを予想させる。すなわち，低温結晶化は， 分子銷の大きな形態変化をともなった液体一結晶の相転 移現象でなく，単なる局所的な形態変化による固体一固 体間の秩序化現象として理解すべきでなからうか。この 分子機構を支持するあう一つの実験的根拠がある。非晶 性PETを延伸して室温でネッキングを起こさせると， 延伸方向への分子配向が起とる。との冷延伸物を赤外吸 収スペクトルで調べると，エチレングリコール部のトラ ンス形態の増加を示す。との場合の組織変換は変形量上 して $300 \%$ 程度であるからすべての分子が引きのばされ たと考えることはできない。トランス形態の増加は，加 なりの部分が未変形単位中の分子銷の局所形態変化飞帰 
せられるととが增加量などから支持される ついては非晶性PETの変形機構上の関連で別化詳しく 報告したい。とのような試料を差動熱量計中で加熱した 結果をととの非晶性無配向PETの結果とともに図 7 に 示した。明らか亿，低温結晶化に基つく発熱ピークは， ストレスで人為的に秩序化さすことによって消失してい る。この現象は，低温結晶化が非晶性PET鎖の大きな 形態変化をともなう拡散によって起こっているのではな 々，局所的な分子銷形態の変化やそれにともなったわず 加銷間の秩序の向上によって進行していると考えるて とに矛盾を示さない。との低温結晶化の分子機構に基つ いた低温結晶化の動力学の解积につてい今後の检討課 題としたい。

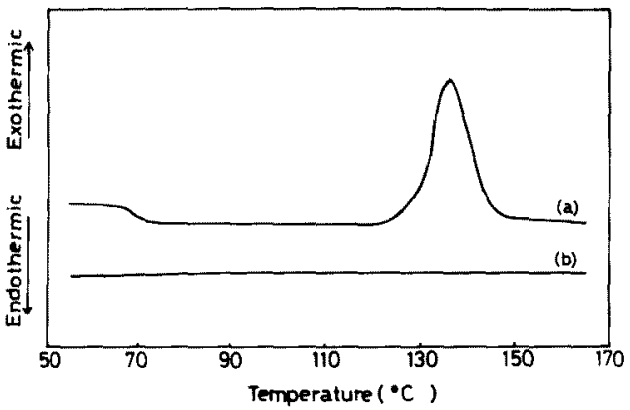

Fig. 7 DSC curves of PET. (a) Original amorphous film. An exothermic peak owing to cold crystallization appears. (b) Cold drawn film. The peak of (a) disappears.

\section{4. 結言}

以上，PETの低温結鼠化について次の上うな点が明 ら加になった。非晶性PETの低温熱処理物の構造は， 形態学的観察から高分子結晶で一般的な折りたたみ銷加 らなる球晶構造であるととを示した。以前，低温熱処理 物の構造を熱挙動等の研究加ら，分子間結晶化倸上る束 状晶であるといった推論があったが，この観察から否定 された。この推諭をなした原因は，非晶性PETの構造 を絡みあったランダムコイル鎖の疑集体之考えたことに あったのかす知れない。最近，河合らあ以前の主張を改 め，われわ机に近い主張を報告している゙て。

また，從来多くの研究者化上って低温結晶化の速度過 程を Avrami 理論で解釈し上うとする試みがなされてきた が，との非晶性固体加らの結晶化については特に Avrami 理論を単純汇適用して解釈するてとの危険性を拐摘した。 この問題の解决の糹口をえるため，てれまでの他の研究 者やわれわれの実験結果を基に低温結晶化の分子機構に
考察を加えた。そして，低温結晶化は非晶性PET銷が 大きな形態变化をともなって結晶界面仙拡散してきて結 晶化する上うなものでなく，非晶性PET中で局所的な 分子銷形態の変化やそれにともなったわずかな銧間の秩 序化によって進行するようなものであると主張した。

本論文は昭和 45 年頃加高分子討論会等 ${ }^{28)}$ で, 断片 的敒発表してきたものをまとめたものである。

\section{文献}

1) H. J. Kolb and E. F. Izard; J. Appl. Phys., 20, 571 (1949)

2) W. H. Cobbs and R. L. Burton: J. Polymer Sci., 10, 275 (1953)

3) A. Keller, G. R. Lester and L. B. Morgan; Philos. Trans. Roy. Soc. London, Ser. A 247, 1 (1954)

4) T. Kawaguchi; J. Polymer Sci., 32, 417 (1958)

5) H. G. Kilian, H. Halboth and E. Jenckel; Kolloid-Z., 172, 166 (1960)

6) H. G. Zachmann and H. A. Stuart; Makromol. Chem., 41, 131 (1960), 52, 23 (1962)

7) 稙松市太郎，植松抜子；高分子化学，17，222 (1960)

8) K. G. Mayhan, W. J. James and W. Bosch; J. Appl. Polym. Sci., 9, 3605 (1965), 9, 3617 (1965)

9) J. R. Collier and E. Baer; J. Appl. Polym. Sci., 10, $1409(1966)$

10) 上田伸夫，温品恭彦；高分子化学， 23，673 (1966)

11) G. S. Y. Yeh and P.H. Geil; J. Macromol. Sci. B1, 235 (1967)

12) K. H. Illers; Kolloid-Z. u. Z. Polymere, 245, 393 (1971)

13) N. D. Scott; Polymer, 1, 114 (1959)

14）三石幸夫，池田守男；高分子化学， 23，310 (1966)

Y. Mitsuishi and M. Ikeda; J. Polymer Sci., A-2 4, 283 (1966)

15）松元孝子，江原勝夫，池上舅，河合徽，前田 弘邦；織維学会誌，25，5(1969)

松元孝子，池上显，江原勝夫，河合 徹，前田 弘邦；工業化学䧴誌， 73，2441(1970)

16）山下祐彦；瀻維上工業，33，P-247(1977)

17) J. L. Koenig and M. J. Hannon; J. Macromol. Sci., B1, 119 (1967)

18）高井良三，金子六郎；高分子化学， 29，336 (1972)

19) G.S. F. Russell and P. S. Pillai; Makromol. Chem., 135, $263(1970)$

20) M. Avrami; J. Chem. Phys., 7, 1103 (1939), 8, 212 (1940), 9, 177 (1941)

21) L. Mandelkern; "Crystallization of Polymers", 
McGraw-Hill Book Company, N.Y., (1964)

22) A. Wlochowicz and W. Przygocki; J. Appl. Polym. Sci., 17, 1197 (1973)

23) W. R. Moore and R. P. Sheldon; Polymer, 2, 315 (1961)

24) R. P. Sheldon; Polymer, 3, 27 (1962)

25) H. G. Zachmann; Kolloid Z. u. Z. Polymere,
189,67 (1963)

26）山下祐彦，物延一男; 末発表データー

27）笹野美子、小川靖夫, 河合 徽; 瀻維学会誌 33，575(1977)

28）山下祐彦，物延一男，小林恵之助; 第 19 回高分子 討諭会講演要旨集 II-863(1970)；第 21 回高分子 討論会講演要旨集 II-549(1972) 